The Canadian Mineralogist

Vol. 42, pp. 683-687 (2004)

\title{
ON THE ROSETTES OF “NATIVE PALLADIUM” FROM MINAS GERAIS, BRAZIL: EVIDENCE FROM GONGO SOCO
}

\author{
Alexandre RaphaEl CABRAL \\ Rua Coelho Neto, 32/704, 22231-110 Rio de Janeiro, RJ, Brazil \\ ROGERIO KWITKO-RIBEIRO \\ Centro de Desenvolvimento Mineral, Companhia Vale do Rio Doce, BR 262/km 296, \\ Caixa Postal 09, 33030-970 Santa Luzia, MG, Brazil
}

\begin{abstract}
Minute rosette-like crystals $(\sim 1 \mu \mathrm{m})$ were found on the surface of a gold nugget from Gongo Soco, an iron ore deposit in Minas Gerais, Brazil. The rosettes consist essentially of palladium with some oxygen. The presence of oxygen and the occurrence of many of the rosettes on a coating of iron oxyhydroxide suggest that the rosettes crystallized from a Pd-O precursor that precipitated from aqueous solution, probably in the supergene environment, on the pre-existing gold nugget.
\end{abstract}

Keywords: rosettes, oxygen-bearing palladium, gold nugget, Gongo Soco, Minas Gerais, Brazil.

\section{SOMMAIRE}

De très petits cristaux $(\sim 1 \mu \mathrm{m})$ en rosettes ont été déposés sur la surface d'une pépite d'or trouvée à Gongo Soco, gisement de fer à Minas Gerais, au Brésil. Ces rosettes contiennent essentiellement du palladium avec de l'oxygène. D'après la présence d'oxygène et la déposition de plusieurs de ces rosettes sur une couche d'oxyhydroxyde de fer, nous croyons que ces rosettes ont cristallisé à partir d'un précurseur de $\mathrm{Pd}-\mathrm{O}$ déposé d'un solution aqueuse sur la pépite pré-existante, probablement dans un milieu supergène.

(Traduit par la Rédaction)

Mots-clés: rosettes, palladium avec oxygène, pépite d'or, Gongo Soco, Minas Gerais, Brésil.

\section{INTRODUCTION}

The remobilization of platinum-group elements (PGE) at low temperatures has been debated in the past decades. One of the questions refers to secondary growth of platinum-group minerals (PGM) in laterites (e.g., Bowles 1986, 1995). The neoformation of PGM in the supergene environment has been advocated by some authors, whereas others have concluded that the PGM in placer deposits are of magmatic origin [vide Wood (2002) for a comprehensive list of references]. Recently, observations on detrital PGM from the Makwiro River, Zimbabwe, have pointed to a low-temperature origin for native platinum occurring as a coating on grains of sperrylite (Oberthür et al. 2003). In their opinion, grains of $\mathrm{Pt}-\mathrm{Fe}$ alloy formed in the supergene environment from a pre-existing PGM (possibly by selective leaching) or as a result of precipitation from an aqueous solution. Precipitates from hydrothermal solutions, formed at a relatively low temperature, were recognized as the precursor of virtually $\mathrm{Fe}$-free native platinum in the Waterberg district of South Africa (Wagner 1929, McDonald et al. 1999a).

The native palladium found in the state of Minas Gerais, Brazil, constitutes one of the most intriguing cases of PGM formed under low-temperature conditions. The occurrence of native palladium as a mineral species was noted for the first time in the early 1800 s, when Wollaston (1809) investigated samples from gold mines in Brazil, possibly from Minas Gerais [vide Atencio (2000) for a discussion of the provenance of the samples]. Hussak (1904) detected grains of native

§E-mail addresses: cabral70tricolor@yahoo.com.br, rogerio.kwitko@cvrd.com.br 
palladium in residual concentrates from the gold washing at Itabira, later identified by electron-microprobe analysis (Olivo \& Gauthier 1995). Also at Itabira, rosette-like crystals of native palladium were found on a crust of iron oxyhydroxide on Pd-bearing gold (Kwitko et al. 2002). Those authors, however, refrained from interpreting the origin of the rosettes. The same roseshaped morphology has now been discovered at Gongo Soco, an iron ore deposit situated about $50 \mathrm{~km}$ southwest of Itabira, where Au-Pd-bearing specular hematite-rich veins, analogous to those at Itabira, occur. This remarkable rosette-like morphology of Pd-rich crystals is documented and discussed here.

\section{Gongo Soco and Sample Material}

Gongo Soco was a famous gold mine in the 19th century (Henwood 1871, Hussak 1904); now it is one of numerous iron ore mines of the Quadrilátero Ferrífero [vide Cabral et al. (2003b) for a geological map]. The Pd-bearing auriferous mineralization occurs as crosscutting veins and veinlets (locally known as jacutinga) in soft hematite ore and in itabirite immediately adjacent to it. The term itabirite denotes a laminated, metamorphosed, iron-rich sedimentary rock (banded iron formation). Both the soft hematite and itabirite have a prominent foliation $\left(\mathrm{S}_{1}\right)$ defined by the planar arrangement of crystals of platy hematite (Cabral et al. 2003b). The $S_{1}$ foliation is generally attributed elsewhere in the Quadrilátero Ferrífero to the $\sim 0.6 \mathrm{Ga}$ Brasiliano Orogeny (e.g., Alkmim \& Marshak 1998, Hippertt \& Davis 2000). The jacutinga veins are friable and consist predominantly of specular hematite and subordinate talc, kaolinite, quartz, goethite and manganese oxide (Hussak 1904). Gold, found as nuggets and aggregates intergrown with specular hematite, is typically alloyed with palladium (Henwood 1871, Hussak 1904) and commonly contains inclusions of arsenide-antimonides of palladium [compositionally close to mertieite-II and isomertieite (Cabral et al. 2002b)].

The sample material is a stick-shaped aggregate (nugget) of gold, about $1 \mathrm{~cm}$ long, recovered in a Knelson concentrator at the iron ore plant. The aggregate was investigated at Companhia Vale do Rio Doce (CVRD) with a Philips XL30 scanning electron microscope (SEM), equipped with an EDAX iDX4 Si(Li) super-ultrathin-window energy-dispersion spectrometer (EDS).

\section{The Palladium-Rich Rosettes from Gongo Soco}

The gold aggregate has some silver $(\sim 5 \mathrm{wt} . \%)$ and traces of palladium $(<1 \mathrm{wt} \%$ ). It is sparsely covered by a coating of goethite-like iron oxyhydroxide. The ferruginous coating and the gold are partially covered by randomly spaced particles (Fig. 1a). Under higher magnification, the particles exhibit a rosette-like morphology, being thinly dispersed on the gold surface (Fig. 1b).
An EDS spectrum of one of the rosettes resting on the gold surface, without any obvious association with iron oxyhydroxide, shows that the mineral is composed essentially of palladium, with minor amounts of oxygen, copper and iron (Fig. 1c). EDS spectra of rosettes on the goethite-like coating and on the gold surface are essentially the same (ignoring interference from the substrate). The Pd-rich rosettes also form aggregates (Figs. $1 \mathrm{~d}, \mathrm{e})$. A single rosette consists of discs that intersect in apparently three orthogonal directions (Fig. 1f).

\section{Discussion And Conclusions}

The presence of oxygen in what initially appeared to be native palladium casts doubt on the rosettes of "native palladium" described by Kwitko et al. (2002) in sample material from Itabira. Oxygen was recognized in the rosettes from Itabira, but attributed to the subjacent iron oxyhydroxide.

At Gongo Soco, Cabral \& Lehmann (2003) found native palladium derived from $\mathrm{Pd}-\mathrm{O}$ masses that formed at the expense of a pre-existing arsenide-antimonide of palladium. The Pd-rich rosettes described here differ from that case because no relics of a primary $\mathrm{Pd}-\mathrm{Sb}-\mathrm{As}$ mineral were detected. Instead of a primary PGM, the rosettes seem to have crystallized as a $\mathrm{Pd}-\mathrm{O}$ phase that precipitated directly from aqueous solution. An analogous case is the $\mathrm{Pt}-\mathrm{O}$ precursor to the native platinum in the Waterberg district of South Africa (Wagner 1929, McDonald et al. 1999a). As suggested for the Waterberg district, deoxygenation and dewatering at low temperatures could be responsible for the crystallization of native palladium from $\mathrm{Pd}-\mathrm{O}$ precipitates. In the Waterberg district, native platinum is intimately associated with specular hematite (Wagner 1929, McDonald et al. 1995), and the crystallization of native platinum from the $\mathrm{Pt}-\mathrm{O}$ precipitate is interpreted to have occurred at temperatures of $100-200^{\circ} \mathrm{C}$ (McDonald et al. 1999a). Lower temperatures than those are envisaged for Gongo Soco and Itabira, since the Pd-rich rosettes are scattered over a goethite-like coating, which is possibly of supergene origin.

The Pd-rich rosettes precipitated not only on the coating of iron oxyhydroxide, but also directly on the surface of gold (Fig. 1b). In this connection, Gammons et al. (1993) emphasized that the steep decrease in solubility of palladium in the presence of gold-rich alloys could be an effective mechanism of precipitation. This mechanism may explain why palladium is apparently not dispersed in the weathered host-rock (itabirite), but restricted to the jacuting a veins.

Quantitative electron-microprobe analyses of the Gongo Soco rosettes are hampered by the small grainsize $(<2 \mu \mathrm{m}$, Fig. 1f). However, electron-microprobe analyses of $\mathrm{Pd}-\mathrm{O}$ alteration halos on arsenide-antimonide of palladium indicate the existence of an oxygen-deficient $\mathrm{Pd}-\mathrm{Cu}$ phase (Cabral et al. 2003a) and a significant negative linear correlation between oxygen 

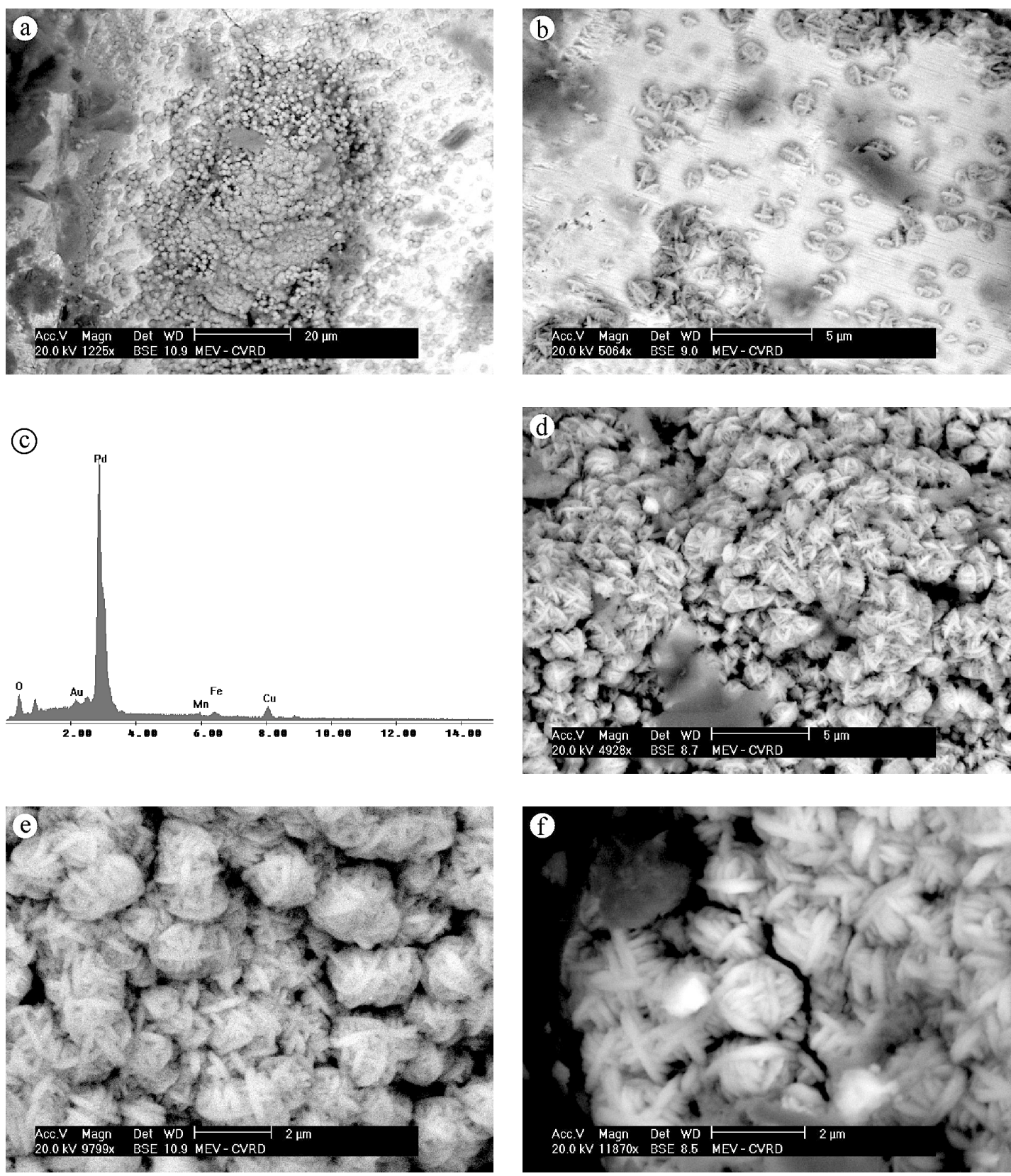

FIG. 1. Back-scattered electron (BSE) images and energy-dispersion spectrum (EDS) of Pd-rich rosettes from Gongo Soco. (a) Light grayish spots are scattered over iron oxyhydroxide (center, dark gray) and gold (white). (b) Under higher magnification, the spots exhibit a rosette-like morphology. They rest on gold (white). (c) Energy-dispersion spectrum of a rosette, consisting essentially of palladium, with subordinate amounts of oxygen, copper, iron and manganese. (d) Cluster of Pd-rich rosettes. (e) Close-up of an aggregate of rosettes. (f) Detail of a rosette (center), showing the intersecting discs apparently at three orthogonal directions ( $c f$. Fig. 9d, Kwitko et al. 2002). 
and palladium (Cabral \& Lehmann 2003), suggesting a transitional range from an empirically derived $\mathrm{PdO}$-like stoichiometry to native palladium, where native palladium would likely be the stable phase of palladium under supergene conditions (Cabral et al. 2004). Considering a hydrated palladium oxide, McDonald et al. (1999b) proposed that recurrent heating during the tropical dry season would eventually dehydrate it to native palladium. It is intriguing, but speculative, that the rosette-like morphology can be compared to those of efflorescences ("desert roses") formed by evaporation in a dry climate.

It was not possible to define whether the Pd-rich rosettes are true $\mathrm{PdO}$ (or a palladium hydroxide or hydrated compound) or an oxygen-deficient phase close to native palladium. Whatever the case, this study gives evidence for the neoformation of PGM at low temperatures. Possibly, the Pd-rich rosettes are supergene in origin, formed under oxidizing conditions (stability field of hematite). Palladium and platinum alloys that formed within the stability field of hematite at low temperatures are also known from other localities in Brazil. They are exemplified by the dendritic and botryoidal $\mathrm{Pt}$ and $\mathrm{Pt}-$ Pd alloys from Córrego Bom Sucesso, Minas Gerais (Cassedanne et al. 1996, Fleet et al. 2002, and references therein), and the Pd and veinlet Pt from the Serra Pelada area, Carajás mineral province, Pará (Cabral et al. 2002a).

\section{ACKNOWLEDGEMENTS}

Sincere thanks go to the Companhia Vale do Rio Doce (CVRD) for the SEM facilities and to the Gongo Soco mine staff, particularly Orlando Garcia, Antônio Abdo, Muriel Innocentini, Edivando, Toco, Pimenta, Antônio "Negão", just to name a few, for the inestimable support during field work. John F. W. Bowles, an anonymous referee and Robert F. Martin kindly revised the manuscript and helped to improve it.

\section{REFERENCES}

AlKmim, F.F. \& MarshaK, S. (1998): Transamazonian orogeny in the southern São Francisco craton region, Minas Gerais, Brazil: evidence for Paleoproterozoic collision and collapse in the Quadrilátero Ferrífero. Precamb. Res. 90, 29-58.

Atencio, D. (2000): Type Mineralogy of Brazil. Instituto de Geociências, Universidade de São Paulo, São Paulo, Brazil.

BowLES, J.F.W. (1986): The development of platinum-group minerals in laterites. Econ. Geol. 81, 1278-1285.

(1995): The development of platinum-group minerals (PGM) in laterites: mineral morphology. Chron. Rech. Minière 63(520), 55-63.
Cabral, A.R. \& LehmanN, B. (2003): A two-stage process of native palladium formation at low temperatures: evidence from a palladian gold nugget (Gongo Soco iron ore mine, Minas Gerais, Brazil). Mineral. Mag. 67, 453-463.

, Grambole, D. \& Herrmann, F. (2004): Hydrogen in a natural Pd-O compound from Gongo Soco, Minas Gerais, Brazil. Can. Mineral. 42, 689-694.

Kwitko-Ribeiro, R. \& CRavo Costa, C.H. (2002a): Palladium and platinum minerals from the Serra Pelada $\mathrm{Au}-\mathrm{Pd}-\mathrm{Pt}$ deposit, Carajás mineral province, northern Brazil. Can. Mineral. 40, 1451-1463.

\& JONES, R.D. (2002b): Palladian gold and palladium arsenide-antimonide minerals from Gongo Soco iron ore mine, Quadrilátero Ferrífero, Minas Gerais, Brazil. Appl. Earth Sci. (Trans. Inst. Mining Metall. B) 111, 74-80.

\& Rocha FiLHO,

O.G. (2003a): On the association of palladium-bearing gold, hematite and gypsum in an ouro preto nugget. Can. Mineral. 41, 473-478.

, ROCHA FILHO, O.G. \& JONES, R.D. (2003b): Hydrothermal origin of soft hematite ore in the Quadrilátero Ferrífero of Minas Gerais, Brazil: petrographic evidence from the Gongo Soco iron ore deposit. Appl. Earth Sci. (Trans. Inst. Mining Metall. B) 112, 279-286.

Cassedanne, J.P., Jedwab, J. \& Alves, J.N. (1996): Apport d'une prospection systématique à l'étude de l'origine de l'or et du platine alluviaux du Córrego Bom Sucesso (Serro - Minas Gerais). An. Acad. Bras. Ciências 68, 569-582.

Fleet, M.E., De Almeida, C.M. \& Angeli, N. (2002): Botryoidal platinum, palladium and potarite from the Bom Sucesso stream, Minas Gerais, Brazil: compositional zoning and origin. Can. Mineral. 40, 341-355.

Gammons, C.H., Yu, Y. \& Bloom, M.S. (1993): Experimental investigation of the hydrothermal geochemistry of platinum and palladium. III. The solubility of $\mathrm{Ag}-\mathrm{Pd}$ alloy $+\mathrm{AgCl}$ in $\mathrm{NaCl} / \mathrm{HCl}$ solutions at $300^{\circ} \mathrm{C}$. Geochim. Cosmochim. Acta 57, 2469-2479.

Henwood, W.J. (1871): On the gold mines of Minas Geraes, in Brazil. Trans. R. Geol. Soc. Cornwall 8, 168-370.

HIPPERTT, J. \& DAvis, B. (2000): Dome emplacement and formation of kilometre-scale synclines in a granite-greenstone terrain (Quadrilátero Ferrífero, southeastern Brazil). Precamb. Res. 102, 99-121.

Hussak, E. (1904): Über das Vorkommen von Palladium und Platin in Brasilien. Sitzungsberichte der mathematischnaturwissenschaftlichen Klasse der Kaiserlichen Akademie der Wissenschaften 113, 379-468.

Kwitko, R., Cabral, A.R., Lehmann, B., Laflamme, J.H.G., Cabri, L.J., Criddle, A.J. \& Galbiatti, H.F. (2002): Hongshiite, $\mathrm{PtCu}$, from itabirite-hosted Au-Pd-Pt miner- 
alization (jacutinga), Itabira district, Minas Gerais, Brazil. Can. Mineral. 40, 711-723.

McDonald, I., Ohnenstetter, D., Rowe, J.P., Tredoux, M., PATTRICK, R.A.D. \& VAUGHAN, D.J. (1999a): Platinum precipitation in the Waterberg deposit, Naboomspruit, South Africa. S. Afr. J. Geol. 102, 184-191.

Ohnenstetter, M. \& Vaughan, D.J. (1999b): Palladium oxides in ultramafic complexes near Lavatrafo, western Adriamena, Madagascar. Mineral. Mag. 63, 345-352.

Vaughan, D.J. \& Tredoux, M. (1995): Platinum mineralization in quartz veins near Naboomspruit, central Transvaal. Trans. Geol. Soc. S. Afr. 98, 168-175.

OBERThÜR, T., WeISER, T.W. \& GAST, L. (2003): Geochemistry and mineralogy of platinum-group elements at Hartley platinum mine, Zimbabwe. 2. Supergene redistribution in the oxidized Main Sulfide Zone of the Great Dyke, and alluvial platinum-group minerals. Mineral. Deposita 38, 344355 .
Olivo, G.R. \& GAUTHIER, M. (1995): Palladium minerals from the Cauê iron mine, Itabira district, Minas Gerais, Brazil. Mineral. Mag. 59, 455-463.

Wagner, P.A. (1929): The Platinum Deposits and Mines of South Africa. Oliver and Boyd, Edinburgh, U.K.

Wollaston, W.H. (1809): On platina and native palladium from Brasil. Phil. Trans. R. Soc. London 99, 189-194.

Wood, S.A. (2002): The aqueous geochemistry of platinumgroup elements with applications to ore deposits. In The Geology, Geochemistry, Mineralogy and Mineral Beneficiation of Platinum-Group Elements (L.J. Cabri, ed.). Can. Inst. Mining Metall. Petroleum, Spec. Vol. 54, 211-249.

Received August 29, 2003, revised manuscript accepted March 25,2004 